\title{
Matkakohteen luontoympäristön vetovoimaisuuden ylläpitäminen maisema- ja virkistysarvokaupan avulla
}

Henna Konu, Luonnonvarakeskus (Luke)

Liisa Tyrväinen, Luonnonvarakeskus (Luke)

\section{Luontomaisemien ja monimuotoisuuden tukeminen osana matkailun toimintaympäristöä}

Luonto on tullut monille yhä tärkeämmäksi koronakriisin aikana, sillä se on tarjonnut mahdollisuuden liikkumiseen ja uusiin paikkoihin tutustumiseen turvalliseksi koetulla tavalla. Vapaaaikaa on vietetty enemmän luontokohteissa, mikä on heijastunut myös luontomatkailun suosioon. Suomalaiset ovat suunnanneet matkojaan kaupunkikeskusten ulkopuolelle, ja kiinnostus luontokohteita kohtaan näkyy muun muassa kansallispuistojen kasvaneissa kävijämäärissä (Metsähallitus, 2020). Luontomatkailu ei kuitenkaan suuntaudu pelkästään kansallispuistoihin tai muille suojelualueille vaan myös matkakohteisiin, joiden ympäristössä on paljon yksityisten maanomistajien alueita ja metsiä.

Keskustelu luontokohteiden säilymisestä ja hyödyntämisestä matkailukäytössä on kohdistunut pitkälti valtion omistamien luonnonsuojelualueiden ja näiden infrastruktuurin ylläpitoon. Vähemmän huomiota on kiinnitetty siihen, miten voidaan turvata matkailun edellytyksiä kauniisiin maisemiin pohjautuvissa luontokohteissa, jotka ovat yksityisten ihmisten tai perheiden omistuksessa (Tyrväinen ym., 2014b) ja joihin kohdistuu erilaisia käyttöpaineita eri sektoreilta (esim. Reed \& Stringer, 2016).

Suomessa metsät kattavat valtaosan maanpinta-alasta, mutta metsänomistajille ei ole tällä hetkellä taloudellisia kannustimia maisemien ja virkistysarvojen turvaamiseksi (esim. Mäntymaa ym., 2019). Kansallisen METSO-ohjelman avulla tuetaan luonnon monimuotoisuuden säilyttämistä erityisesti Etelä-Suomen yksityismetsissä, mikä osaltaan turvaa myös maisemien säilymistä. Luonnonsuojeluun kerätään myös vapaaehtoisia lahjoituksia vapaaehtoisjärjestöjen ja säätiöiden toimesta. Yksityiset suojelualueet ovat kuitenkin usein sijainniltaan hankalasti 
saavutettavissa, eivätkä ne välttämättä ole suoraan matkailukäytössä tai hyödytä muutoin matkailutoimialaa. Kaikkiaan maisemien tai muiden aineettomien luontoarvojen säilyttäminen matkailua varten ei toistaiseksi ole saanut laajemmin huomiota metsäpolitiikassa eikä maankäytön suunnittelussa (Tyrväinen ym., 2020). Metsien käyttöön liittyvissä keskusteluissa onkin usein tuotu esille eri käyttömuotojen, kuten metsätalouden, luonnonsuojelun ja virkistyskäytön, ristiriidat.

Matkailun vastuullisuuspyrkimykset ovat nostaneet esille myös laajemman kysymyksen siitä, millä tavalla matkailutoimialan ja matkailuyritysten tulisi huomioida kestävyyden eri osaalueet omassa toiminnassaan. Luontoympäristön huomioiminen ja suojelu ovat osa ekologista kestävyyttä, ja ne linkittyvät osaksi yritysten vastuullisuustoimia. Tähänastiset ympäristön kestävyyttä edistävät toimenpiteet ovat pääasiassa painottuneet muun muassa energiaratkaisuihin sekä energian ja veden säästämiseen, mikä tuo taloudellista hyötyä yrityksille (esim. Font ym., 2016). Tulisiko matkailusektorin osallistua vahvemmin myös sellaisiin kestävyyttä edistäviin toimintoihin, jotka eivät välttämättä suoraan heijastu yrityksen taloudellisen kestävyyden parantamiseen vaan laajemmin toimintaympäristöstä huolehtimiseen? Toimialalla on yrityksiä, jotka tunnistavat luontomaisemien säilyttämisen merkityksen omien arvojensa ja liiketoimintansa näkökulmasta ja toimivat sen mukaisesti, mutta laajassa mittakaavassa matkailutoimiala ei ole toistaiseksi osallistunut luontomaisemien säilyttämiseen tai ylläpitoon kovinkaan aktiivisesti (Aapala ym., 2017; Mäntymaa ym., 2019). Yhtenä syynä tähän on ollut asiaa tukevien käytänteiden ja toimintamallien puuttuminen.

\section{Matkailun kestävyyden edistäminen maisema- ja virkistysarvokaupan avulla}

Jotta matkailutoimiala panostaisi luontoympäristön hoitoon ja suojeluun, tulee toimintaan osallistuminen tehdä mahdollisimman helpoksi. Kansainvälisellä tasolla on vain muutamia toimintamalleja, joissa matkailutoimijat voivat olla mukana edistämässä tai joilla matkailutoimiala on sitoutettu tukemaan luontoympäristöjen säilymistä. Yksi esimerkki on Vietnamissa toteutettu malli, joka edellyttää metsäympäristöstä hyötyvien matkailuyritysten maksavan tietyn osuuden liikevaihdostaan valtiolle, ja valtio ohjaa varat edelleen maisemien ja monimuotoisuuden suojeluun (Nguyen ym., 2017). Kyseessä on siis valtion taholta määrätty toimintatapa, joka sisältää pakollisen maksuvelvoitteen. Suomessa ei ole käytössä vastaavanlaisia maksuja, joita voitaisiin ohjata matkailutoimialaa hyödyttävään luontoympäristöjen vaalimiseen.

Matkailutoiminta tuo monille alueille taloudellista hyötyä, mutta yksityiset maanomistajat eivät juurikaan hyödy taloudellisesti alueen matkailukäytöstä. Julkisten ohjauskeinojen puuttuessa on keskusteluihin tuotu mukaan niin sanotut markkinalähtöiset toimintamallit ekosysteemipalvelujen tuottamisessa (market-based mechanisms). Näiden avulla matkailutuloa voitaisiin kohdentaa maisemien ja monimuotoisuuden säilyttämiseen myös yksityisille maanomistajille. Esimerkkinä tällaisesta toimintamallista on Ruka-Kuusamon alueelle kehitetty maisemaja virkistysarvokauppamalli, jonka avulla voidaan turvata kauniiden maisemien ja luonnon monimuotoisuuden säilymistä alueen yksityismetsissä sekä ylläpitää alueen luontomatkailun 
edellytyksiä. Malli pohjautuu aiempaan tutkimukseen ja laajoihin taustaselvityksiin erilaisista olemassa olevista toimintamalleista, ja sen kehittämisessä on huomioitu eri toimijoiden - matkailijoiden, matkailuyrittäjien ja metsänomistajien - näkemyksiä (ks. esim. Kurttila ym., 2019; Mäntymaa ym., 2018, 2019; Tyrväinen ym., 2014a, 2020).

Luonto on Kuusamon alueen matkailun keskeinen vetovoimatekijä. Useat alueen matkailuyrittäjät keskittyvätkin erilaisten luonnossa tapahtuvien matkailupalveluiden tarjoamiseen. Näin ollen luontoympäristön viihtyisyydellä, maisemilla ja monipuolisuudella on keskeinen rooli matkailijoiden elämyksissä. Ruka-Kuusamossa maisema- ja virkistysarvokaupassa mukana olevat metsäkohteet onkin valittu alueilta, jotka ovat matkailun näkökulmasta keskeisiä. Näitä ovat esimerkiksi erilaisten ulkoilureittien varret sekä maisemapaikoilta avautuvat näkymät. Valitut metsäkohteet ovat iältään uudistuskypsiä, ja talousmetsien hoitosuositusten mukaan niissä tehtäisiin päätehakkuu uuden taimikon aikaansaamiseksi.

Koska toiminnan tavoitteena on edistää maisemien ja monimuotoisuuden säilymistä yksityisten metsänomistajien alueilla pitkällä aikavälillä, tulee toiminnassa huomioida myös maanomistajien näkökulma ja tulonlähteet. Nykyisin pääosa metsänomistajien tuloista tulee puun myynnistä. Uuden mallin avulla yksityisille metsänomistajille voidaan korvata tulonmenetykset, mikäli he sitoutuvat tietyksi määräajaksi vapaaehtoisesti suojelemaan tai käsittelemään metsäalueitaan sovitusti maisema- ja virkistysarvot huomioon ottaen. Sen lisäksi, että mallin piirissä olevat metsät valitaan matkailun kannalta merkityksellisiltä alueilta, huomioidaan metsän ikä, alueen maisema-arvo, luonnon monimuotoisuus ja metsän rooli hiilivarastona.

Maisema- ja virkistysarvokaupan tavoitteena on siis tuoda monipuolisia hyötyjä matkakohteen eri toimijoille. Matkailun toimintaympäristön säilymisen lisäksi toimintamalli tuo monenlaisia hyötyjä niin matkailuyrityksille kuin alueelle laajemmin. Muun muassa alueen imago vastuullisena ja kestävänä matkakohteena vahvistuu, mikä osaltaan tukee Ruka-Kuusamon alueen pyrkimyksiä saada matkakohteelle Sustainable Travel Finland -sertifiointi.

Toiminta linkittyy vahvasti kestävyyden periaatteisiin, sillä metsien ekologinen kestävyys paranee maisemia ja luonnon monimuotoisuutta vaalimalla. Matkailutoimialan lisäksi monimuotoisten luontoalueiden säilymisestä hyötyvät sekä matkailijat, mökkien omistajat että paikalliset asukkaat. Ekologisen kestävyyden lisäksi sosiaalinen ja taloudellinen kestävyys paranevat, kun myös yksityiset metsänomistajat hyötyvät alueelle suuntautuvasta matkailusta. Matkailutulon jalkauttaminen myös paikallisille metsänomistajille voi osaltaan vähentää matkailu- ja metsäsektorin välisiä ristiriitoja.

\section{Toimintatavan jalkauttaminen käytäntöön}

Maisema- ja virkistysarvokaupan kehittämiseen ja käytäntöön viemiseen ovat vaikuttaneet monet eri tekijät, kuten oikean toimijan löytäminen rahan keräämiseen ja hallinnointiin, rahan keräämiseen liittyvä lainsäädäntö sekä rahankeräämistavan määrittäminen. Mallia kokeillaan Ruka-Kuusamon alueella syksyn 2020 aikana, jolloin matkailijat voivat osallistua yhdessä muiden toimijoiden kanssa alueen kauniiden maisemien ja luonnon monimuotoisuuden säilyttämiseen antamalla vapaaehtoisia lahjoituksia. Kokeilua arvioidaan eri kestävyyden näkökulmista ja sen 
pohjalta, miten uusi toimintamalli otetaan vastaan. Mielenkiintoista on nähdä, näkyykö esimerkiksi viime aikoina jatkuvasti kasvanut luontoelämysten arvostus myös halukkuutena tukea luontoympäristön säilymistä. Lahjoitusten määrään vaikuttaa myös tietoisuus asiasta, joten pilotin yhtenä keskeisenä tavoitteena onkin yleisen tietoisuuden lisääminen aiheesta.

Pilotin aikana kerätään kokemuksia maisema- ja virkistysarvokauppamallin toimivuudesta jatkokehittämistä ajatellen. Laajempana tavoitteena on saada aikaan pysyvä alueellinen toimintamalli, jonka alueelliset toimijat voivat ottaa omakseen ja jonka periaatteita voisi jatkossa hyödyntää muillakin matkailualueilla. Eri alueilla toimintamallit voivat painottua erilaisten ekosysteemipalveluiden ylläpitämiseen, sisältäen mahdollisesti myös hiilikompensaatiomahdollisuuden. Toiminnan onnistumiseen vaikuttavat kuitenkin vahvasti paikallisten toimijoiden sitoutuminen sen rahoittamiseen ja hallinnointiin sekä toiminnan ymmärrettävyys ja hyväksyttävyys eri sidosryhmien keskuudessa.

Suomessa on totuttu liikkumaan luonnossa jokamiehenoikeuden turvin eikä luonnosta nauttimisesta ole tarvinnut maksaa. Korona-aika on lisännyt luonnon merkitystä ja luonnossa oleskelua. On mielenkiintoista nähdä, missä määrin poikkeuksellinen aika vaikuttaa matkailijoiden arvoihin ja asenteisiin. Konkretisoituvatko mahdolliset muutokset esimerkiksi lahjoituksina, jotka kohdistuvat matkailijoille tärkeiden maisemien ja ympäristöjen ylläpitämiseen? Koronan vaikutukset heijastuvat luonnollisesti myös matkailuyritysten liiketoimintaan ja resursseihin. Kriisistä toipumisessa - ja sen jälkeen - korostuvat joka tapauksessa matkailun kestävyyteen liittyvät asiat. Edellä esitelty maisema- ja virkistysarvokauppa on yksi keino säilyttää yhteinen toimintaympäristömme niin matkailijoille, paikallisille toimijoille kuin itse luonnolle.

\section{Lisätietoja:}

Maisema- ja virkistysarvokauppamallin kehittäminen ja testaaminen on osa kansainvälistä Euroopan Unionin Horisontti 2020 -rahoitteista SINCERE-hanketta (GA no. 773702), jossa kehitetään metsien maisema-, virkistys- ja luontoarvoja säilyttäviä toimintamalleja eri puolilla Eurooppaa (https://sincereforests.eu/). Maisema- ja virkistysarvokauppamallia kehitetään Kuusamossa Luonnonvarakeskuksen ja Suomen metsäkeskuksen johdolla, ja mallin kokeilu toteutetaan yhteistyönä Ruka-Kuusamon Matkailuyhdistyksen kanssa (https:/www.ruka.fi/ maisema-arvokauppa). Mallin pilotoinnin aikana rahan keräämisestä ja hallinnoinnista vastaa paikallisella tasolla Ruka-Kuusamon Matkailuyhdistys.

\section{Lähteet}

Aapala, K., Tyrväinen, L., Reinikainen, M., Lehtoranta, V., Usva, K., Ojala, O. \& Vihervaara, P. (2017). Uusia keinoja vetovoimaisen luonnon turvaamiseen. (Valtioneuvoston selvitys- ja tutkimustoiminnan julkaisusarja 83/2017.)

Font, X., Garay, L. \& Jones, S. (2016). Sustainability motivations and practices in small tourism enterprises in European protected areas. Journal of Cleaner Production, 137(November), 14391448. https://doi.org/10.1016/j.jclepro.2014.01.071 
Kurttila, M., Mäntymaa, E., Juutinen, A., Hujala, T. \& Tyrväinen, L. (2019). Multi-criteria analysis process for creation and evaluation of PES alternatives in the Ruka-Kuusamo tourism area. Journal of environmental planning and management, 63(10), 1857-1879. https://doi.org/10.1080/096 40568.2019.1689933

Metsähallitus (2020). Kansallispuistojen käyntimäärässä kova kasvu - Kansallispuistojen palveluilla selkeä kysyntä. https://www.metsa.fi/tiedotteet/kansallispuistojen-kayntimaarassa-kova-kasvu-kansallispuistojen-palveluilla-selkea-kysynta/

Mäntymaa, E., Ovaskainen, V., Juutinen, A. \& Tyrväinen, L. (2018). Participation and compensation claims in voluntary forest landscape conservation: The case of the Ruka-Kuusamo tourism area, Finland. Journal of Forest Economics, 33, 14-24. https://doi.org/10.1016/j.jfe.2018.09.003

Mäntymaa, E., Tyrväinen, L., Juutinen, A. \& Kurttila, M. (2019). Importance of forest landscape quality for companies operating in nature tourism areas. Land Use Policy. https://doi. org/10.1016/j.landusepol.2019.104095

Nguyen, V. H., Hoang, T. H. \& Nguyen, H. N. (2017). Payment for forest environmental services in tourism in Vietnam. https:/www.researchgate.net/publication/321011344_Payment_for_Forest_Environmental_Services_in_Tourism_in_Vietnam

Reed M. S. \& Stringer, L. C. (2016). Land degradation, desertification and climate change: Anticipating, assessing and adapting to future change. Routledge.

Tyrväinen, L., Mäntymaa, E. \& Ovaskainen, V. (2014a). Demand for enhanced forest amenities in private lands: The case of the Ruka-Kuusamo tourism area, Finland. Forest Policy and Economics, 47, 4-13. https://doi.org/10.1016/j.forpol.2013.05.007

Tyrväinen, L., Mäntymaa, E. \& Ovaskainen, V. (2014b). Maisema-arvokauppa luontomatkailun kehittämismahdollisuutena. Teoksessa L. Tyrväinen, T. Sievänen, S. Tuulentie \& M. Kurttila (toim.), Hyvinvointia metsästä (175-184). Suomalaisen Kirjallisuuden Seura.

Tyrväinen, L., Mäntymaa, E., Juutinen, A., Kurttila, M. \& Ovaskainen, V. (2020). Private landowners' preferences for trading forest landscape and recreational values: A choice experiment application in Kuusamo, Finland. Land Use Policy. https://doi.org/10.1016/j.landusepol.2020.104478 